\title{
A Possible Role of Endoneurial Fibroblast-Like Cells in the Resolution of Endoneurial Oedema Following Nerve Crush Injury
}

\author{
El Posible Rol de los Fibroblastos Endoneurales en la Resolución del Edema \\ Endoneural Después de una Lesión por Aplastamiento Nervioso
}

Wagih G. Elbarrany \& Wardah A. Alasmari

\begin{abstract}
ELBARRANY, W. G. \& ALASMARI, W. A. A possible role of endoneurial fibroblast-like cells in the resolution of endoneurial oedema following nerve crush injury. Int. J. Morphol., 37(1):141-148, 2019.

SUMMARY: Endoneurial oedema is a salient feature of all types of neuropathy. Its elimination is crucial during the complications of nerve recovery. The objective was to study a possible role of the endoneurial fibroblasts in the resolution of nerve edema. Forty-two albino male rats aged between 30 and 40 days (weight $200 \mathrm{~g}$ to $250 \mathrm{~g}$ ) were used in this study. The left sural nerves of 36 rats were subjected to crush injury at one to three-week intervals with six animals per interval. The right and left sural nerves of the remaining six rats were used as controls. At the end of the second week after crush injury, the endoneurium showed channel-like spaces that were lined by fibroblast-like cells and collagen bundles that contained degenerated myelin, and were connected to the subperineurial spaces. Flattened fibroblast-like cells were arranged in several layers in the subperineurial, forming barrier-like cellular sheets localizing to the endoneurial oedema in the space. Fibroblast-like cells also wrapped around the regenerating nerve fibres with their branching cytoplasmic processes. During the third week, the flattened fibroblast-like cells formed nearly continuous cellular sheets in the subperineurial spaces. Macrophages were frequently observed between these cellular barrier-like sheets and in the subperineurial. The endoneurial fibroblast-like cells form barrier-like cellular sheets that probably localise the endoneurial oedema in the subperineurial space. It also appear to create endoneurial channel-like spaces containing degenerated myelin and endoneurial oedema, which may be helpful in localizing and resolving such oedema.
\end{abstract}

KEY WORDS: Sural Nerve; Endoneurial Fibroblast-Like Cells; Endoneurial Oedema; Barrier-Like And Channel-Like Spaces.

\section{INTRODUCTION}

Fibroblast-like cells play a central role in various diseases of different organs, including the synovial membranes of diseased joints (Kontoyiannis \& Kollias, 2000; Mor et al., 2005), the myocardium (Takemura et al., 1998; Hayakawa et al., 2003; Yano et al., 2005), and the liver (Jodon de Villeroché \& Brouty-Boyé, 2008). These cells area mostly differentiated into different types, such as neurons, corneal cells, osteoblasts, chondrocytes, adipocytes, cardiomyocytes, hepatocytes, and pancreatic islet cells. Despite originating from a non-embryonic source, they express stem cell markers that are important for maintaining an undifferentiated state. This multipotent property makes these cells a promising therapeutic target (Dravida et al., 2005; Giovannini et al., 2008). In rheumatoid arthritis, fibroblasts-like cells, called fibroblast-like synovial cells (FLS) stimulate the inflammatory process and directly attack the cartilage and bones. Moreover, FLS modulate the autoimmune response, and are crucial in the pathogenesis of rheumatoid arthritis (Kontoyiannis \& Kollias; Mor et al.). Fibroblast reorganisation is associated with neoplastic progression, and is associated with the inflammatory process, and macrophage recruitment is associated with neoplasia (Coussens \& Werb, 2002; Allinen et al., 2004; Amatangelo et al., 2005).

Fibroblasts control local and distant angiogenesis mediated by bone marrow stem cells; however, they are transformed into invasive types and myofibroblasts (De Wever \& Mareel 2003; Orimo et al., 2005) within the stroma of invasive cancers of the breast, colon, ovaries, pancreas and prostate (Kalluri \& Zeisberg, 2006). After wound injury, fibroblasts are activated and help recruit mesenchymal stem cells that play a role in wound healing (McGee et al., 2013). Cardiac fibroblasts are transformed into myo-fibroblasts, 
which are important in tissue contraction and repair after myocardial infarction (Takemura et al.; Yano et al.). Moreover, they can be converted into a myogenic phenotype, which may be helpful for the treatment or prevention of myocardial infarction (Salvatori et al., 1995; Wise et al., 1996; Etzion et al., 2002; Goldsmith et al., 2004; van Tuyn et al., 2007). The biliary tract and hepatic epithelial cells arise from the portal tracts surrounding ducts, where fibroblasts are abundant (Crosby et al., 2001; Libbrecht et al., 2002; Li et al., 2013; Lemoinne et al., 2013). In vitro studies using fibroblasts from different tissues showed that fibroblasts display distinct behaviour according to the anatomic site and the disease status (Chang et al., 2002; Parsonage et al., 2003).

Endoneurial oedema is a prominent feature in most types of neuropathies (McManis et al., 1986; Olsson, 1989; Pedowitz et al., 1991; Gabreëls-Festen et al., 1993; Eaton et al., 1996; Maxfield et al., 1997). It has a major role in reducing the endoneurial blood flow and subsequent degeneration of the nerve fibres (Maxfield et al.). During nerve regeneration, the endoneurial oedema subsides, leading to decreased endoneurial pressure and increased blood flow (Low et al., 1985; Gonda et al., 2010; Kobashigawa et al., 2011). In diabetic neuropathy, the progressive nerve fibre loss may be attributed to the persistent nature of the endoneurial oedema (Low et al.). Endoneurial oedema accumulates primarily in the subperineurial and perivascular spaces (Pedowitz et al.; Gabreëls-Festen et al.). The reason for this localisation and fate of the accumulated endoneurial oedema in different types of neuropathies remains unclear. The question remains, do fibroblast-like cells have a role in nerve regeneration and the localisation or resolution of endoneurial oedema following nerve injury Therefore, the present study assessed endoneurial fibroblast-like cells and their possible role in the localisation and resolution of endoneurial oedema.

\section{MATERIAL AND METHOD}

Forty-two albino adult male Sprague- Dawley rats were used in this study, weighing 200 to $250 \mathrm{~g}$ and aged 3040 days. A total of 36 rats were initially anaesthetised by ether inhalation, followed by an intraperitoneal injection of penta-barbitone sodium (Sagatal; $60 \mathrm{mg} / \mathrm{ml}$ ) at a dose of 30 $\mathrm{mg} / \mathrm{kg}$ body weight. Anaesthesia was maintained during surgery by repeated intraperitoneal injection of pentabarbitone sodium. The left sural nerves were exposed and subjected to crush injury just distal to its origin from the tibial nerve using non-toothed forceps for 10 seconds. The right and left sural nerves of the remaining 6 rats were used as a control group. At set intervals ranging from 1 to 3 weeks after the nerve crush, 12 animals were re-anaesthetised initially by ether inhalation, and then weighed and injected with penta-barbitone sodium according to their weight. The crushed nerves were re-exposed and collected. A $2.5 \mathrm{~mm}$ segment at the site of the crush was discarded. The remaining nerve was segmented into $2.5 \mathrm{~mm}$ segments, fixed in $2.5 \%$ glutaraldehyde then post-fixed in $2 \%$ osmium tetroxide. The nerve segments were dehydrated in graded concentrations of ethanol and embedded in Araldite resin. Semithin sections of $1 \mu \mathrm{m}$ were obtained and stained with toluidine blue in borax for light microscopy. Ultrathin sections of $0.07 \mu \mathrm{m}$ were stained with uranyl acetate and lead citrate for electron microscopy. Sural nerve segments were also collected from the normal nerves and processed similarly.

\section{Light Microscopic Study}

Light Microscopic Study of Normal Sural Nerves. The endoneurium contained myelinated nerve fibres with different diameters and thicknesses of their myelin sheaths. There were few scattered endoneurial fibroblasts with short cytoplasmic processes throughout the endoneurium without special arrangement. The subperineurial space contained myelinated nerve fibres (Fig. 1A).

Light Microscopic Study of Crushed Nerves. One week after the crush injury, the endoneurium showed a significant increase of the number of endoneurial fibroblasts and fibroblasts-like cells with long cytoplasmic processes. Some were scattered in the endoneurium, whereas others surrounded the regenerating nerve fibres. Fibroblast-like cells surrounded the regenerating nerve fibres. There was an increase in degenerated myelin and endoneurial macrophages (Fig. 1B).

Two weeks after the crush injury, the flattened fibroblast-like cells were arranged in multiple cellular layers in the subperineurial space. The flattened cytoplasmic processes of the fibroblast-like cells were attached in the majority of layers, forming subperineurial barrier-like cellular sheets. Fibroblast-like cells also surrounded the regenerated nerve fibres, isolating them in special compartments. The spaces between the fibroblast-like cellular sheets and perineurium contained accumulated endoneurial oedema, in addition to some of the endoneurial macrophages carrying degenerated myelin (Fig. 1C).

Three weeks after the crush injury, the fibroblast-like cells were arranged in a nearly continuous cellular sheet in the subperineurial space, forming a cellular barrier-like structure. Other cells surrounded the regenerating groups of nerve fibres. The subperineurial space contained endoneurial oedema and endoneurial macrophages (Fig. 2). 

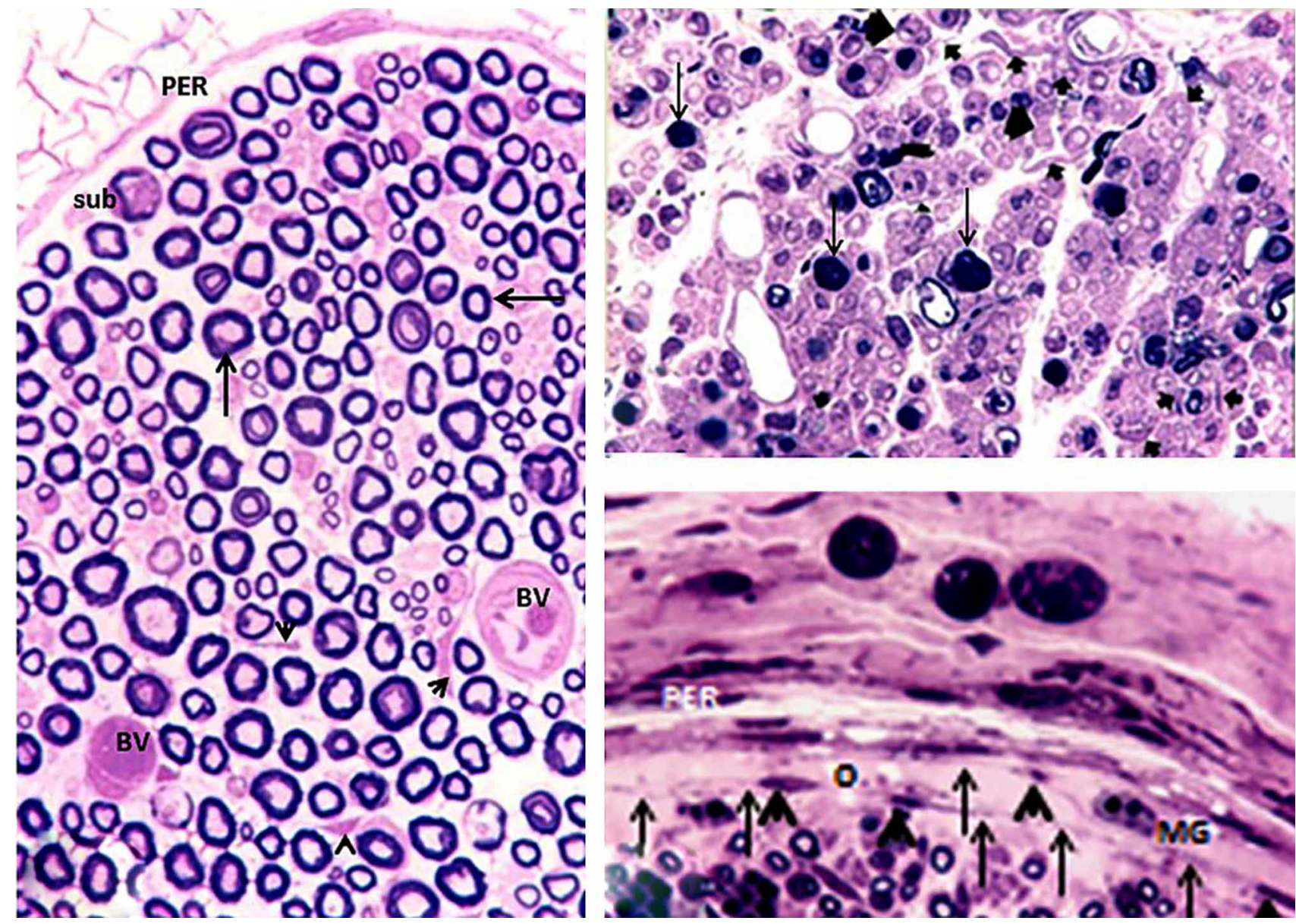

Fig. 1A. A normal sural nerve showing the perineurium (PER), endoneurium containing myelinated nerve fibres (long arrows), few scattered fibroblasts (arrow heads) and the endoneurial blood vessels (BV). B. One week after the crush, there are increased degenerated myelin (long arrows), increased number of endoneurial fibroblasts (short arrows). C. After two weeks of the crush injury, the endoneurial fibroblast-like cells form several cellular sheets in the subperineurial space (arrows) forming barrier-like sheets. O, subperineurial oedema, MG; macrophages, PER; perineurium, BV; blood vessels. X 400.

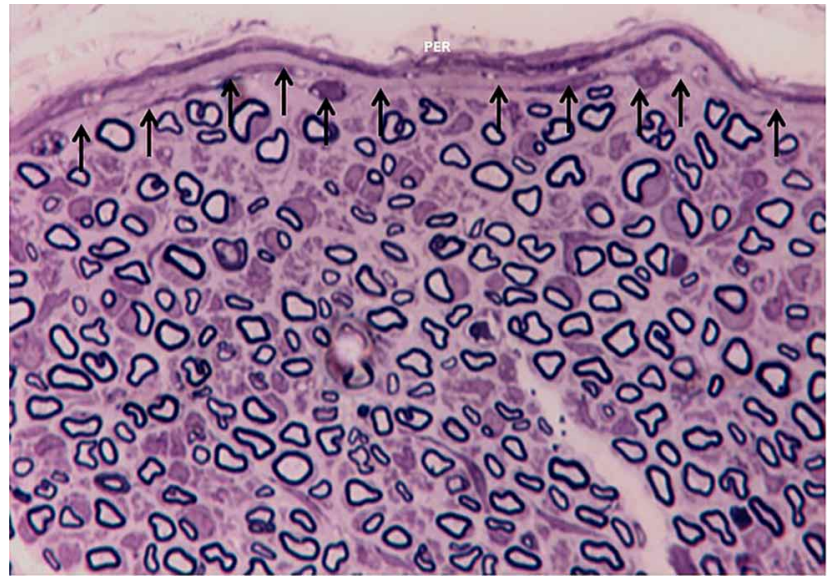

Fig. 2. After three weeks after the crush injury, the endoneurial fibroblast-like cells form a nearly continuous cellular sheet in the subperineurial space (arrows) localizing the subperineurial oedema. PER; perineurium. X 400 .
Electron Microscopic Study

Normal Sural Nerves. The endoneurium showed myelinated and non-myelinated nerve fibres along with collagen bundles together with the endoneurial blood vessels. Endoneurial fibroblasts were few and scattered in the endoneurium, and a few had longer cytoplasmic processes. The subperineurial spaces were filled with collagen bundles and nerve fibres (Fig.3A).

Crushed Sural Nerve. One week after the crush injury, the endoneurium showed the accumulation of endoneurial oedema indicated by the wide separation of collagen fibrils. It showed an increased number of flattened endoneurial fibroblast-like cells, with long cytoplasmic processes that wrapped the regenerating unmyelinated or thinly myelinated nerve fibres, in most of the specimens. There were areas of contact between these cytoplasmic processes and the nearby 
endoneurial macrophages. Some of the endoneurial fibroblasts were flattened and fibroblast-like, whereas others appeared fusiform (Figs. 3B, C).

After two weeks after the crush, the endoneurial fibroblast-like cells were arranged in cellular layers in the subperineurial and around the regenerating nerve fibres, forming barrier-like cellular sheets (Figs. 4). Channel-like spaces appeared in the endoneurium. These spaces are lined by fibroblast-like cells and collagen bundles and contained degenerated myelin debris and accumulated endoneurial oedema. The channel-like spaces were continuous with the subperineurial space. The endoneurial macrophages had areas of contact with the endoneurial fibroblast-like cells.
The subperineurial barrier-like sheets were interrupted where the channel-like spaces communicated the subperineurial space and also where the endoneurial macrophages were located (Fig. 4). The endoneurium was divided into areas of regenerated nerve fibres surrounded by the cytoplasmic processes of the fibroblast-like cells (Fig. 4).

During the third week after the crush injury, the endoneurial fibroblast-like cells were apparently decreased in number, with the disappearance of most of the endoneurial channel-like spaces. The fibroblast-like cells wrapped the regenerating nerve fibres in most of the specimens and formed single subperineurial cellular sheet (Fig. 5).
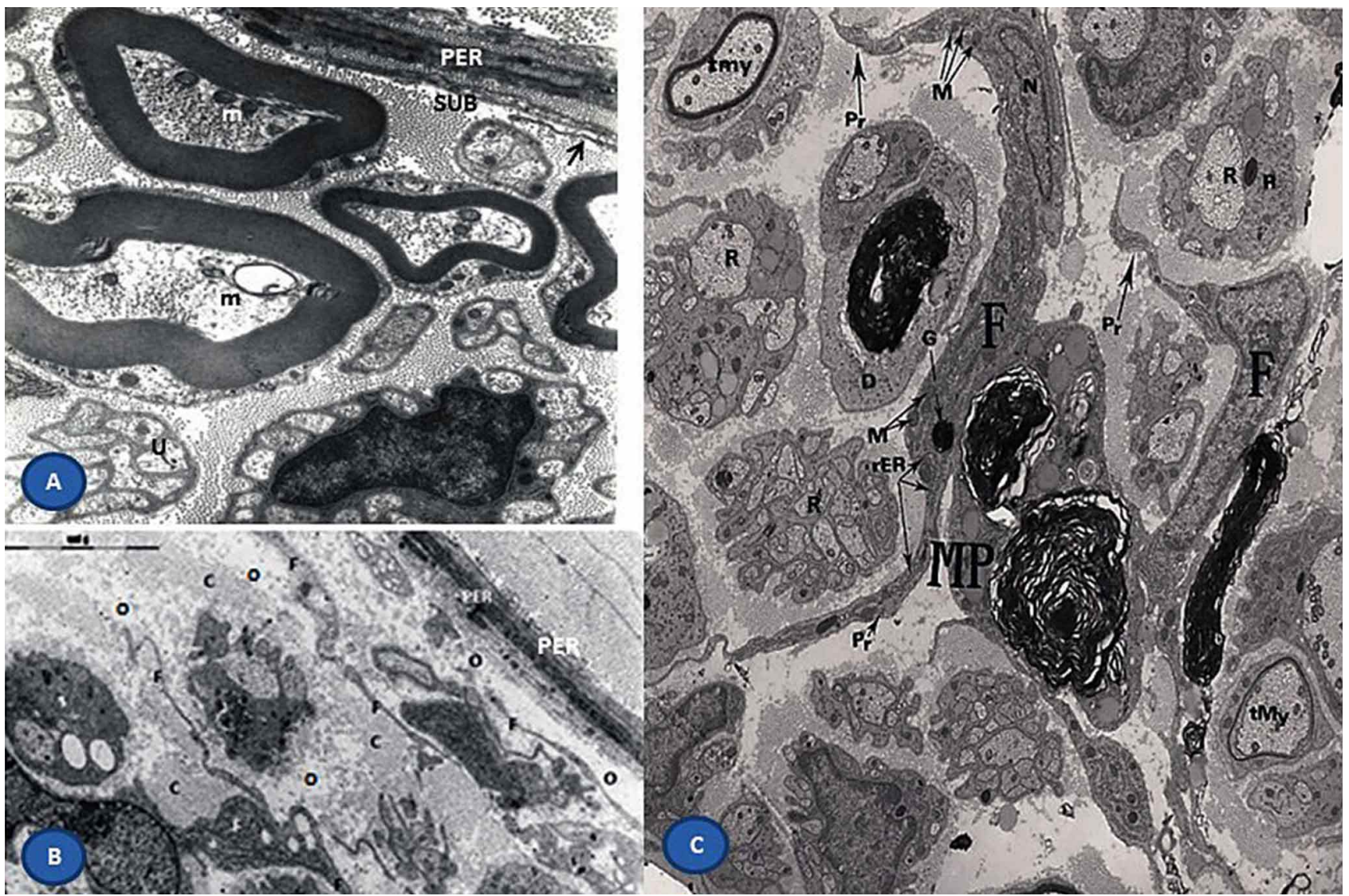

Fig.3. A. Normal sural nerve with myelinated (m), unmyelinated $(\mathrm{u})$ nerve fibres and collagen bundles $(\mathrm{C})$ in the subperineurial (SUB) space. PER, perineurium. Scalebar $1 \mu \mathrm{m}$. B. One week after crush injury, the endoneurial fibroblast $(\mathrm{F})$ and the endoneurial fibroblastlike cells were increased in the subperineurial space among the regenerating nerve fibres, there is accumulation of endoneurial oedema (O). Scale bar, $5 \mu \mathrm{m}$. C. Endoneurial fibroblasts with long cytoplasmic processes (pr), with cytoplasmic rough endoplasmic reticulum (rER) and mitochondria (M) that partially surrounded the regenerating nerve fibres (R) and have areas of contacts with the endoneurial macrophage (MG), one week after the crush. Scale bar, $2 \mu \mathrm{m}$.

\section{DISCUSSION}

Traumatic nerve injury and various pathological conditions result in the accumulation of endoneurial oedema; a salient feature in most types of neuropathies (Pedowitz et $a l$; Gabreëls-Festen et al.). Diabetes is one of the most 

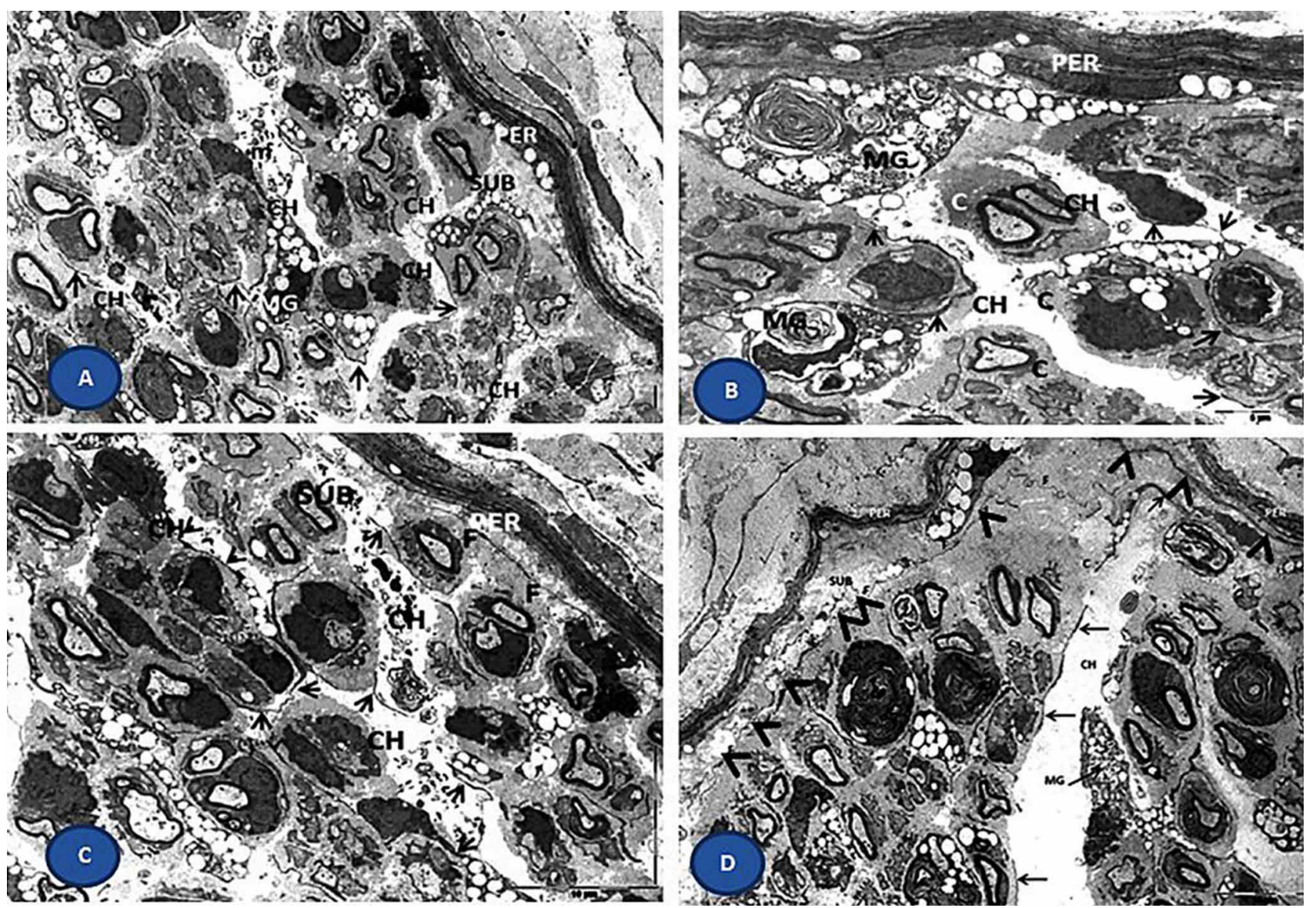

Fig. 4. The sural nerve after 2 weeks of the crush injury shows the endoneurial channel-like spaces $(\mathrm{CH})$ lined by fibroblast-like cells (arrows) and collagen bundles (C). They contain degenerated myelin and endoneurial macrophages (MG), and some are continuous with the subperineurial (Figs. 5A-5D). Fig. 5D shows subperineurial cellular barrier-like sheets of fibroblast-like cells (arrow heads). PER, perineurium. Scale bars $10 \mu \mathrm{m}, 2 \mu \mathrm{m}, 10 \mu \mathrm{m}$ and $10 \mu \mathrm{m}$, respectively.
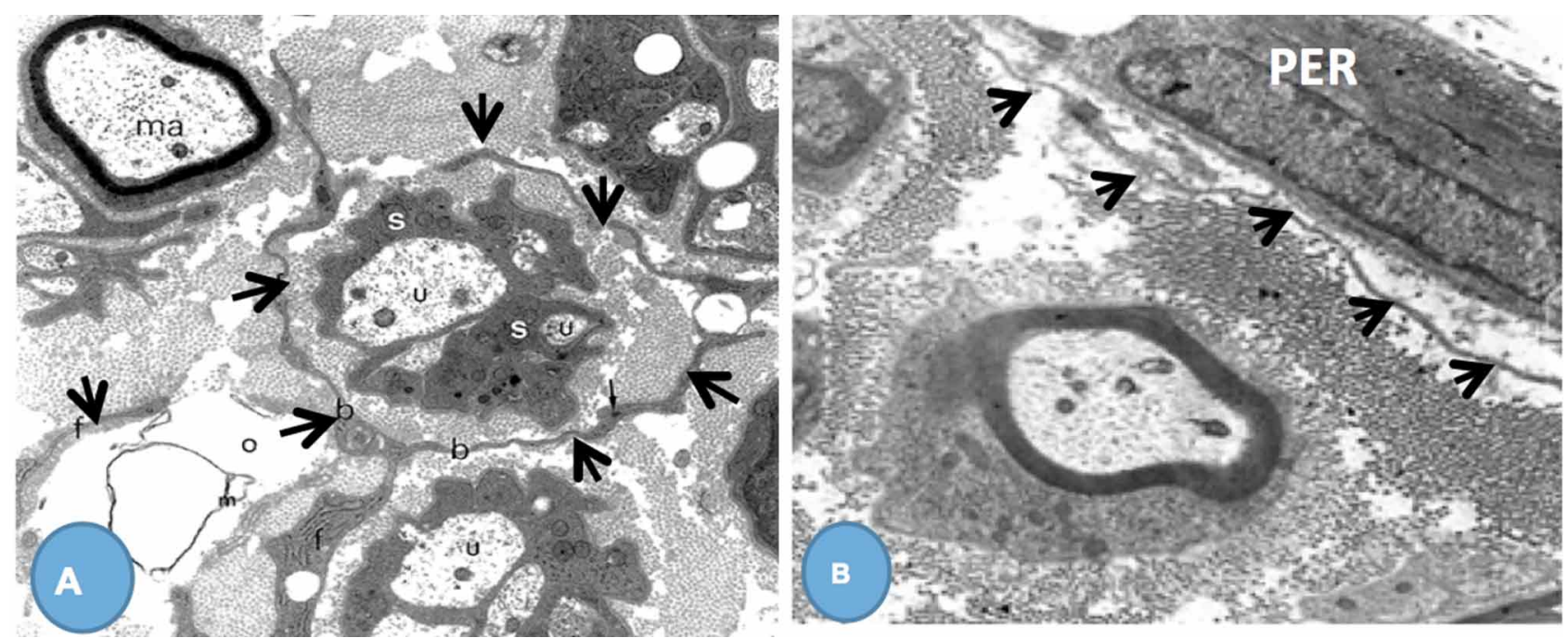

Fig. 5. The sural nerve during the third week after crush injury showing the endoneurial fibroblast-like cells (arrows) surrounding the regenerating nerve fibres in A. and form cellular sheet in the subperineurial space in B. PER, perineurium; ma, myelinated nerve fibres; s, Schwann cells, o, oedema; u, unmyelinated nerve fibers 
common diseases that produce persistent peripheral neuritis as a result at least partially to the resulting endoneurial oedema secondary to effects on the vasa nervosa of the peripheral nerves (McManis et al.; Maxfield et al.).

Accumulation of endoneurial oedema is a result of damage to the blood-nerve barrier, which is consisted of the endoneurial blood vessels and the inner cellular layer of the perineurium. Consequently, the permeability of the endoneurial blood vessels increases and the accumulation of endoneurial oedema more in the subperineurial and perivascular spaces, although there is no clear explanation for such sites of accumulation (Pedowitz et al.). It results in an increase of intraneural pressure, which in turn reduces the blood flow in the endoneurium and endoneurial oxygen tension. The mechanical affection of the perineurial and epineurial blood vessels are observed to be resulted in degeneration of the nerve fibres (Low et al.; Gonda et al., 2010).

Ultra-structural studies of the recovering crushed peripheral nerves showed marked progressive reduction of the endoneurial oedema until it resolves completely (Pedowitz et al.; Gabreëls-Festen et al.). Consequently, nerve recovery after traumatic or pathological injury depends mainly on the resolution of endoneurial oedema, thus decreasing the intraneural pressure and increasing the endoneurial blood flow. It was reported that the maximum accumulation of endoneurial oedema was during the second week following the traumatic injury to the peripheral nerve, which coincides with the maximum increased permeability of the blood-nerve barrier (Pedowitz et al.). The rate of resolution of such an oedema will match the rate of functional nerve recovery. The fate of the endoneurial oedema, together with the cellular events and mechanisms of its resolution, remain unclear.

The present study showed that differentiated endoneurial fibroblast-like cells, in the segments distal to the site of the crush injury of the sural nerve, were apparently increased. These cells were flattened with long branching cytoplasmic processes that contained, in many cases, pinocytotic vesicles with areas of contacts in between. During the second week after nerve crush injury, the flattened fibroblast-like cells formed cellular barrier-like layers in the subperineurial space. During the third week following crush injury, a barrier-like cellular layer was a complete sheet of cells interrupted at sites where the endoneurial oedema communicated with the subperineurial oedema. The cellular sheet made by the fibroblast-like cells were isolated from the inner cellular layer of the perineurium by the accumulated subperineurial oedema which could explain the subperineurial accumulation of the endoneurial oedema following nerve injury.
The current study also showed that the fibroblastlike cellular barrier-like sheets probably aimed at supporting the disturbed inner cellular layer of the perineurium; one site of the blood-nerve barrier. Such subperineurial accumulation of oedema could also increase the fluid pressure in the subperineurial, which may help in the absorption of the endoneurial oedema through the perineurium into the epineurial blood vessels. The scattered endoneurial fibroblasts and the absence of fibroblast-like cellular barrier-like sheets in the normal nerves may support this hypothesis.

During the current study, the endoneurial fibroblastlike cells together with the collagen bundles wrapped around groups of the regenerated nerve fibres, thus creating endoneurial channel-like spaces in-between. These spaces were bounded on both sides by fibroblast-like cells and collagen bundles and contained degenerated myelin and endoneurial oedema. In most of the specimens, endoneurial macrophages made part of the wall of these channel-like spaces. The subperineurial space was in the communication of these spaces in certain areas of the endoneurium. Therefore, endoneurial oedema can reach the subperineurial where its absorption and resolution can occur. It is suggested that movements of the long processes of the fibroblast-like cells may create a current for the direction of the endoneurial oedema in these spaces towards the subperineurial. Moreover, isolation of the regenerated nerve fibres by fibroblast-like cells can help the regenerative process of the nerve fibers.

The stroma of the tumours contains an increased number of cancer-associated fibroblasts (CAFs) which are pro tumorigenic. There is growing evidence that CAFs are genetically different from the normal fibroblasts and could be potential targets for anti-cancer therapy.

Evidence that is epigenetically and possibly also genetically distinct from normal fibroblasts is beginning to define these cells as potential targets for anti-cancer therapy (Kobashigawa et al., 2011). On the other hand researchers found that the blood-borne fibroblast-like cells have the common surface markers of the hematopoietic stem cells CD34 (37).

Endoneurial Fibroblast-Like Cells might represent around 2 percent to 9 percent of the endoneurial cells. The spindle shaped cells on electron microscopy (EM) with rectangular or triangular bodies of cells when viewed in the transcerse section. They have long processes of cytoplasmic that expands either laterally between nerve fibers or along the nerve trunk; these types of processes usually loosely interdigitate with the neighbouring endoneurial 
fibroblast-like cells and also enclose one or various Schwann cells. In contrast with the Schwann cell nuclei, their nuclei seem paler and their cell membrane represents micropinocytotic vesicles in smooth invaginations. The cytoplasm of endoneurial fibroblast-like cells contains Golgi apparatus, prominent endoplasmic reticulum and scattered mitochondria which is frequently orientated and is dilated in places and more or less in parallel arrays. Granular material is present in the cisternae. These cells comprise of only a few lysosomes in normal nerves. It is very complex to distinguish between extremely convoluted cells and intracytoplasmic vacuolation observed in cross section. Intermittently, the cytoplasm of endoneurial fibroblast-like cells is invaginated by bundles of collagen that is present in the plasma membrane with direct contact (Richard et al., 2012, 2014).

\section{CONCLUSION}

The results indicated that fibroblast-like cells might play an important role in localising the endoneurial oedema in the subperineurial space by forming barrier-like cellular sheets. These cells also lined channel-like endoneurial spaces that containeddegenerated myelin and oedema and are continuous with the sub-perineurial space. Consequently, fibroblast-like cells may play an important role in the localization of endoneurial oedema following crush injury. Immunohistochemistry study of the fibroblast-like cells in normal and crushed nerves is recommended.

\section{ACKNOWLEDGMENT}

Thanks to Dr. Faris M. Altaf for his valuable help during the experimental work and photographing.

ELBARRANY, W. G. \& ALASMARI, W.A. El posible rol de los fibroblastos endoneurales en la resolución del edema endoneural después de una lesión por aplastamiento nervioso. Int. J. Morphol., 37(1):141-148, 2019.

RESUMEN: El edema endoneural es una característica destacada de todos los tipos de neuropatía. Su eliminación es importante durante las complicaciones de la recuperación nerviosa. El objetivo fue estudiar un posible papel de los fibroblastos endoneurales en la resolución del edema nervioso. En este estudio se utilizaron 42 ratas macho albinas con edades entre los 30 y 40 días (peso 200 a 250 g). Los nervios surales izquierdos de 36 ratas se sometieron a lesiones por aplastamiento en intervalos de una a tres semanas con seis animales por intervalo. Se usaron los nervios surales derecho e izquierdo de las seis ratas restantes como controles. Al final de la segunda semana después de la lesión por aplastamiento, el endoneuro mostró espacios en forma de canal que estaban revestidos por células similares a fibroblastos y haces de colágeno que contenían mielina degenerada y se conectaron a los espacios subperineurales. Las células aplanadas de fibroblastos se dispusieron en varias capas en el subperineuro, formando láminas celulares de tipo barrera que se localizaban en el espacio del edema endoneural. Las células similares a fibroblastos también envolvían las fibras nerviosas regeneradoras con sus procesos citoplásmicos ramificados. Durante la tercera semana, las células aplanadas de fibroblastos formaron láminas celulares casi continuas en los espacios subperineurales. Los macrófagos se observaron con frecuencia entre estas láminas similares a barreras celulares y en el subperineuro. Las células de tipo fibroblasto endoneural formaban láminas celulares de tipo barrera que probablemente localizan el edema endoneural en el espacio subperineural. También parece que crea espacios en forma de canal endoneural que contienen mielina degenerada y edema endoneural, que pueden ser útiles para localizar y resolver este edema.

PALABRAS CLAVE: Nervio sural; Células similares a fibroblastos endoneurales; Edema endoneural; Barreras y Espacios semejantes a canales.

\section{REFERENCES}

Allinen, M.; Beroukhim, R.; Cai, L.; Brennan, C.; Lahti-Domenici, J.; Huang, H.; Porter, D.; Hu, M.; Chin, L.; Richardson, A.; Schnitt, S.; Sellers, W. R. \& Polyak, K. Molecular characterization of the tumor microenvironment in breast cancer. Cancer Cell, 6(1):17-32, 2004.

Amatangelo, M. D.; Bassi, D. E.; Klein-Szanto, A. J. \& Cukierman, E. Stroma-derived three-dimensional matrices are necessary and sufficient to promote desmoplastic differentiation of normal fibroblasts. Am. J. Pathol., 167(2):475-88, 2005.

Chang, H. Y.; Chi, J. T.; Dudoit, S.; Bondre, C.; van de Rijn, M.; Botstein, D. \& Brown, P. O. Diversity, topographic differentiation, and positional memory in human fibroblasts. Proc. Natl. Acad. Sci. U. S. A., 99(20):12877-82, 2002.

Coussens, L. M. \& Werb, Z. Inflammation and cancer. Nature, 420(6917):860-7, 2002.

Crosby, H. A.; Kelly, D. A. \& Strain, A. J. Human hepatic stem-like cells isolated using c-kit or CD34 can differentiate into biliary epithelium. Gastroenterology, 120(2):534-44, 2001.

De Wever, O. \& Mareel, M. Role of tissue stroma in cancer cell invasion. J. Pathol., 200(4):429-47, 2003.

Dravida, S.; Pal, R.; Khanna, A.; Tipnis, S. P.; Ravindran, G. \& Khan, F. The transdifferentiation potential of limbal fibroblast-like cells. Brain Res. Dev. Brain Res., 160(2):239-51, 2005.

Eaton, R. P.; Qualls, C.; Bicknell, J.; Sibbitt, W. L. Jr.; King, M. K. \& Griffey, R. H. Structure-function relationships within peripheral nerves in diabetic neuropathy: the hydration hypothesis. Diabetologia, 39(4):439-46, 1996.

Etzion, S.; Barbash, I. M.; Feinberg, M. S.; Zarin, P.; Miller, L.; Guetta, E.; Holbova, R.; Kloner, R. A.; Kedes, L. H. \& Leor, J. Cellular cardiomyoplasty of cardiac fibroblasts by adenoviral delivery of MyoD ex vivo: an unlimited source of cells for myocardial repair. Circulation, 106(12 Suppl. 1):I125-30, 2002. 
Gabreëls-Festen, A. A.; Gabreëls, F. J.; Hoogendijk, J. E.; Bolhuis, P. A.; Jongen, P. J. \& Vingerhoets, H. M. Chronic inflammatorydemyelinating polyneuropathy or hereditary motor and sensory neuropathy? Diagnostic value of morphological criteria. Acta Neuropathol., 86(6):630-5, 1993.

Giovannini, S.; Brehm, W.; Mainil-Varlet, P. \& Nesic, D. Multilineage differentiation potential of equine blood-derived fibroblast-like cells. Differentiation, 76(2):118-29, 2008.

Goldsmith, E. C.; Hoffman, A.; Morales, M. O.; Potts, J. D.; Price, R. L.; McFadden, A.; Bice, m. \& Borg, T. K. Organization of fibroblasts in the heart. Dev. Dyn., 230(4):787-94, 2004.

Hayakawa, K.; Takemura, G.; Kanoh, M.; Li, Y.; Koda, M.; Kawase, Y.; Maruyama, R.; Okada, H.; Minatoguchi, S.; Fujiwara, T. \& Fujiwara, H. Inhibition of granulation tissue cell apoptosis during the subacute stage of myocardial infarction improves cardiac remodeling and dysfunction at the chronic stage. Circulation, 108(1):104-9, 2003.

Jodon de Villeroché, V. \& Brouty-Boyé, D. Establishment and characterization of atypical fibroblasts from human adult liver contributing to hepatocyte cord-like arrangement. Cell. Biol. Int., 32(6):605-14, 2008.

Kalluri, R. \& Zeisberg, M. Fibroblasts in cancer. Nat. Rev. Cancer, 6(5):392401, 2006.

Kontoyiannis, D. \& Kollias, G. Fibroblast biology. Synovial fibroblasts in rheumatoid arthritis: leading role or chorus line? Arthritis Res., 2(5):3423,2000 .

Lemoinne, S.; Cadoret, A.; El Mourabit, H.; Thabut, D. \& Housset, C. Origins and functions of liver myofibroblasts. Biochim. Biophys. Acta, 1832(7):948-54, 2013.

Li, Y.; Wang, J. \& Asahina, K. Mesothelial cells give rise to hepatic stellate cells and myofibroblasts via mesothelial-mesenchymal transition in liver injury. Proc. Natl. Acad. Sci. U. S. A., 110(6):2324-9, 2013.

Libbrecht, L.; Cassiman, D.; Desmet, V. \& Roskams, T. The correlation between portal myofibroblasts and development of intrahepatic bile ducts and arterial branches in human liver. Liver, 22(3):252-8, 2002.

Low, P. A.; Nukada, H.; Schmelzer, J. D.; Tuck, R. R. \& Dyck, P. J. Endoneurial oxygen tension and radial topography in nerve edema. Brain Res., 341(1):147-54, 1985.

Maxfield, E. K.; Cameron, N. E. \& Cotter, M. A. Effects of diabetes on reactivity of sciatic vasa nervorum in rats. J. Diabetes Complications, 11(1):47-55, 1997.

McGee, H. M.; Schmidt, B. A.; Booth, C. J.; Yancopoulos, G. D.; Valenzuela, D. M.; Murphy, A. J.; Stevens, S.; Flavell, R. A. \& Horsley, V. IL-22 promotes fibroblast-mediated wound repair in the skin. J. Invest. Dermatol., 133(5):1321-9, 2013.

McManis, P. G.; Low, P. A. \& Yao, J. K. Relationship between nerve blood flow and intercapillary distance in peripheral nerve edema. Am. J. Physiol., 251(1 Pt. 1):E92-7, 1986.

Mor, A.; Abramson, S. B. \& Pillinger, M. H. The fibroblast-like synovial cell in rheumatoid arthritis: a key player in inflammation and joint destruction. Clin. Immunol., 115(2):118-28, 2005.

Olsson, Y. Microenvironment of the peripheral nervous system under normal and pathological conditions. Crit. Rev. Neurobiol., 5(3):265-311, 1989.

Orimo, A.; Gupta, P. B.; Sgroi, D. C.; Arenzana-Seisdedos, F.; Delaunay, T.; Naeem, R.; Carey, V. J.; Richardson, A. L. \& Weinberg, R. A. Stromal fibroblasts present in invasive human breast carcinomas promote tumor growth and angiogenesis through elevated SDF-1/CXCL12 secretion. Cell, 121(3):335-48, 2005.

Parsonage, G.; Falciani, F.; Burman, A.; Filer, A.; Ross, E.; Bofill, M.; Martin, S.; Salmon, M. \& Buckley, C. D. Global gene expression profiles in fibroblasts from synovial, skin and lymphoid tissue reveals distinct cytokine and chemokine expression patterns. Thromb. Haemost., 90(4):688-97, 2003

Pedowitz, R. A.; Nordborg, C.; Rosenqvist, A. \& Rydevik, B. L. Nerve function and structure beneath and distal to a pneumatic tourniquet applied to rabbit hindlimbs. Scand. J. Plast. Reconstr. Surg. Hand. Surg., 25(2):109-20, 1991.

Richard, L.; Topilko, P.; Magy, L.; Decouvelaere, A. V.; Charnay, P.; Funalot, B. \& Vallat, J. M. Endoneurial fibroblast-like cells. J. Neuropathol. Exp. Neurol., 71(11):938-47, 2012.
Richard, L.; Védrenne, N.; Vallat, J. M. \& Funalot, B. Characterization of endoneurial fibroblast-like cells from human and rat peripheral nerves. J. Histochem. Cytochem., 62(6):424-35, 2014.

Salvatori, G.; Lattanzi, L.; Coletta, M.; Aguanno, S.; Vivarelli, E.; Kelly, R.; Ferrari, G.; Harris, A. J.; Mavilio, F. \& Molinaro, M. Myogenic conversion of mammalian fibroblasts induced by differentiating muscle cells. J. Cell. Sci., 108(Pt. 8):2733-9, 1995.

Takemura, G.; Ohno, M.; Hayakawa, Y.; Misao, J.; Kanoh, M.; Ohno, A.; Uno, Y.; Minatoguchi, S.; Fujiwara, T. \& Fujiwara, H. Role of apoptosis in the disappearance of infiltrated and proliferated interstitial cells after myocardial infarction. Circ. Res., 82(11):1130-8, 1998

van Tuyn, J.; Pijnappels, D. A.; de Vries, A. A.; de Vries, I.; van der Veldevan Dijke, I.; Knaän-Shanzer, S.; van der Laarse, A.; Schalij, M. J. \& Atsma, D. E. Fibroblasts from human postmyocardial infarction scars acquire properties of cardiomyocytes after transduction with a recombinant myocardin gene. F. A. S. E. B. J., 21(12):3369-79, 2007.

Wise, C. J.; Watt, D. J. \& Jones, G. E. Conversion of dermal fibroblasts to a myogenic lineage is induced by a soluble factor derived from myoblasts. J. Cell. Biochem., 61(3):363-74, 1996.

Yano, T.; Miura, T.; Ikeda, Y.; Matsuda, E.; Saito, K.; Miki, T.; Kobayashi, H.; Nishino, Y.; Ohtani, S. \& Shimamoto, K. Intracardiac fibroblasts, but not bone marrow derived cells, are the origin of myofibroblasts in myocardial infarct repair. Cardiovasc. Pathol., 14(5):241-6, 2005.
Corresponding author:

Wagih G. Elbarrany

Anatomy Department

Faculty of Medicine

Umm Al-Qura University

Makkah

KSA

SAUDI ARABIA

Email: elbarrany@yahoo.com

Received: 17-09-2018

Accepted: 12-01-2019 